DOI: https://doi.org/10.32836/2521-666X/2020-68-19

УДК 658.1:075.8

\author{
Геліч Н.В. \\ кандидат економічних наук, доцент, \\ Східноєвропейський національний університет імені Лесі Українки \\ Басараб В.В. \\ студентка, \\ Східноєвропейський національний університет імені Лесі Українки \\ Шабала О.В. \\ студентка, \\ Східноєвропейський національний університет імені Лесі Українки
}

\author{
Gelich Nataliia, Basarab Viktoriia, Shabala Olha \\ Lesya Ukrainka Eastern European National University
}

\title{
ЗАБЕЗПЕЧЕННЯ ІННОВАЦІЙНОГО РОЗВИТКУ ПІДПРИЄМСТВА
}

\section{ENSURING INNOVATIVE DEVELOPMENT OF THE ENTERPRISE}

У статті розглянуто основні складники інноваційного потенціалу. Ефективна інноваційна політика забезпечує підприємству сталий економічний розвиток. Виявлено особливості маркетингу в управлінні інноваційним розвитком підприємства. Удосконалено організаџійний механізм виведення інновачії на ринок. Виконано аналіз підходів до застосування інструментів і методів маркетингу в інновачійної діяльності підприємств. Окреслено основні чинники, щяо впливають на вибір певноі стратегї збуту інновачій. Розглянуто характеристики елементів збуту нового товару. Визначено специфіку сучасного інструментарію маркетингу інновачій. Запропоновано розробити методичний інструментарій для проведення аналітичних досліджень в інноваційній системі та пропозицій щзодо стимулювання інноваційної активності підприємств.

Ключові слова: маркетингова інноващійна діяльність, маркетинг інноващій, інновачійна продукція, маркетингові страmегії збуту.

В статье рассмотрены основные составляющие инноващионного потенщиала. Эффективная инноващионная политика обеспечивает предприятию устойчивое экономическое развитие. Выявлены особенности маркетинга в управлении инновационным развитием предприятия. Усовершенствован организационный механизм вывода инновачии на рынок. Выполнен анализ подходов к применению инструментов и методов маркетинга в инновационной деятельности предприятий. Определены основные факторы, влияющие на выбор определенной стратегии сбыта инноваиий. Рассмотрены характеристики элементов сбыта нового товара. Определена специфика современного инструментария маркетинга инноваций. Предложено разработать методический инструментарий для проведения аналитических исследований в инновачионной системе и предложений по стимулированию инновационной активности предприятий.

Ключевые слова: маркетинговая инновационная деятельность, маркетинг инноващий, инноващионная продукция, маркетинговые стратегии сбыта.

The current stage of development of Ukraine is characterized by the intensification of scientific and innovative activities, which is one of the determining factors of structural adjustment and acceleration of economic growth. An innovative product must not only be created, but also mastered in production, it must be perceived by the market and potential buyers. One of the most important problems to ensure the success of innovation must be considered the effectiveness of interaction between different market participants: business owners, employees, consumers, the state. Of particular relevance is the development of a fundamentally new mechanism for bringing 
innovation to market, which will increase the efficiency of the enterprise, taking into account the interests of all stakeholders. An effective innovation policy of the enterprise is one of the most important conditions for ensuring its sustainable economic development. At the present stage of development of Ukraine, the intensification of scientific and innovative activities should be one of the determining factors of structural adjustment and acceleration of economic growth. The main thing in innovation management was and is the correctness of the decision and the prediction of strategic prospects for the development of the company based on the compliance of marketing strategy to the goals and real capabilities of the enterprise. practical activity of enterprises, all stages of work with the assessment and choice of strategy can be carried out in parallel, the results of such work in crisis conditions are the basis for the survival of the enterprise. Given the limited investment resources, the process of forming a strategy for innovative development of the enterprise should involve radical changes in the model of economic development of the country. A necessary prerequisite for this is the development of an appropriate state strategy for all stakeholders in society. Such a strategy implies the need to move to the European path of development. To do this, it is necessary to develop methodological tools for conducting analytical research and forecasting in the innovation system, as well as to develop proposals for stimulating innovation activity of enterprises.

Key words: marketing innovation, innovation marketing, innovative products, marketing strategies.

Постановка проблеми. Сучасний етап розвитку України характеризується активізацією науково-інноваційної діяльності, що є одним із визначальних факторів структурної перебудови та прискорення економічного зростання. Інноваційний продукт потрібно не тільки створити, а й освоїти у виробництві, він повинен бути сприйнятий ринком та потенційними покупцями.

Однією 3 найважливіших проблем забезпечення успішності інноваційної діяльності необхідно вважати ефективність взаємодії різних учасників ринку: власників підприємств, працівників, споживачів, держави. Особливої актуальності набуває розроблення принципово нового механізму виведення інновації на ринок, який сприятиме підвищенню ефективності підприємства з урахуванням інтересів усіх зацікавлених сторін.

Аналіз останніх досліджень і публікацій. Дослідженню проблеми вибору стратегії та методів забезпечення інноваційного розвитку присвячено багато наукових праць. Основні засади управління інноваційною діяльністю викладені у працях учених: І. Ансоффа, П. Друкера, М. Портера, Й. Шумпетера та ін. Особливості інноваційної діяльності підприємств України досліджували О.І. Амоша, Т.А. Васильєва, В.М. Гриньова, М.П. Денисенко, С.М. Ілляшенко, Н.В. Коваленко, П.Г. Перерва, I.М. Труніна, А.І. Яковлєв та ін. Проведені наукові дослідження виявили, що управління інноваційним розвитком підприємства орієнтоване на стабільні економічні умови господарювання. Однак нерозкритими залишаються питання забезпечення ефективності інноваційного розвитку підприємства.

Мета статті полягає в аналізі науково-інноваційної діяльності, що зумовлюється тим, що приріст обсягів збуту та доходів відбувається на тих підприємствах, які впроваджують інновації. Також доцільно виявити тенденції розвитку ринку для просування на ньому нових високоякісних товарів, орієнтованих на задоволення потреб споживачів.

Виклад основного матеріалу дослідження. С три складники інноваційного потенціалу: ресурсний; внутрішній; результативний. Ці складники співіснують взаємно, зумовлюють один одного і реалізуються як поєднання трьох складників одразу [4, с. 29].

До ресурсного складника належать: природні ресурси; матеріально-технічні ресурси; людські ресурси; інформаційні ресурси; фінансові ресурси.
До внутрішнього складника інноваційного потенціалу відносять: систему організацій і управління виробництвом нових видів продукції, нових, удосконалених технологій, винахідницькою та раціоналізаторською діяльністю і впровадженням нових технологій; систему комерціалізації у вигляді зв'язку з ринком інновацій.

До результативного складника відносять: систему маркетингу для дослідження й аналізу попиту; систему пропозицій для науково-технічних робіт, ліцензій, патентів.

Ефективна інноваційна політика підприємства $є$ однією з найважливіших умов забезпечення його сталого економічного розвитку. Розроблення і реалізація інноваційної політики включає визначення пріоритетів інноваційного розвитку, регулювання інноваційної діяльності, підтримку наявних та впровадження нових інновацій, захист інтелектуальної власності та здійснення інших заходів, що стосуються забезпечення інноваційного розвитку підприємства [2].

Інноваційну політику підприємства необхідно постійно переглядати та вдосконалювати, зважаючи на досягнення таких завдань, як [1]: залучення до інноваційної сфери капіталовкладень; формування потрібних інноваційних програм; розвиток пріоритетних напрямів інноваційної діяльності; забезпечення ефективності діяльності інноваційних структур.

Будь-яка діяльність, що пов'язана із впровадженням інновацій, потребує розроблення заходів і методів управління нею задля забезпечення іiі ефективності та досягнення поставлених цілей. Цілями управління інноваційною діяльністю підприємства може бути збільшення прибутку в поточному чи довгостроковому періоді, забезпечення високих темпів економічного розвитку підприємства, збільшення частки ринку тощо [3].

На сучасному етапі розвитку України активізація науково-інноваційної діяльності повинна бути одним iз визначальних факторів структурної перебудови та прискорення економічного зростання.

Сам по собі інноваційний продукт ще не забезпечує успіху на ринку. Новий товар потрібно не тільки створити й освоїти у виробництві, необхідно, щоб він був сприйнятий ринком та потенційними покупцями.

Згідно із запропонованим на рис. 1 організаційним механізмом, цілі, пріоритети та норми підприємства визначають необхідний потік матеріальних та 


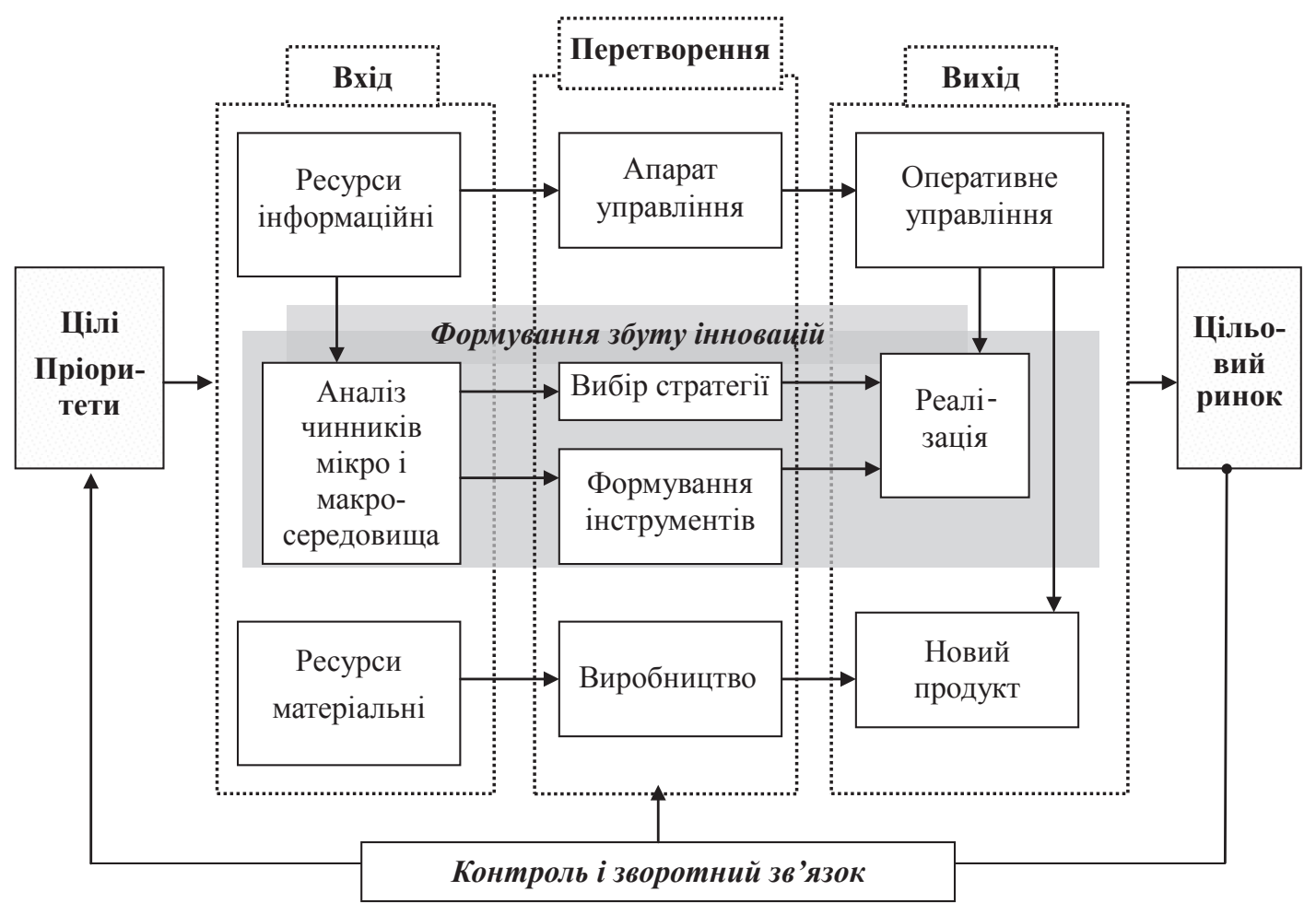

Рис. 1. Організаційний механізм виведення інновації на ринок

Джерело: сформовано на основі [5]

інформаційних ресурсів, або так званий «Вхід» системи. Далі інформаційні потоки надходять до суб'єкта управління, а матеріальні обробляються відповідно до порядку здійснення операцій із метою одержання вихідних результатів - продукту та рішень про його місце на ринку.

Механізм враховує також специфіку інновацій, тому до загальноприйнятої схеми додається рішення про вихід нового товару на ринок та складання комплексу збуту інновації. Інформація про цільовий ринок $\epsilon$ таким же вхідним ресурсом, як і перелічені вище, тобто три ресурсні потоки повинні надходити паралельно у визначеному часовому відрізку.

Обробка інформації та її перетворення на вихідний результат відбувається по мірі необхідності для кожного виду товарів чи послуг та згідно з визначеною метою підприємства.

Організаційний механізм показує, що до моменту появи нового товару на цільовому ринку необхідно мати розроблений механізм збуту, вже узгоджений із визначеними ресурсними обмеженнями та пріоритетами підприємства. За допомогою контролю, зворотного зв'язку з цільовою аудиторісю та з урахуванням впливу зовнішнього середовища будуть змінюватися потоки ресурсів, кожне наступне рішення по цій стратегії буде скориговане для досягнення мети. У відборі й композиції елементів збуту нового товару вирішальну роль відіграють мікро- та макроекономічні фактори, як залежні, так і незалежні від підприємства. Серед них найважливіше значення мають: розмір підприємства; економічна ситуація на підприємстві; прийнята загальна стратегія розвитку підприємства; характер конкурентної боротьби; етап життєвого циклу інновації; вид продукції; характер попиту, ступінь його цінової й рентабельної еластичності.

Незалежно від особливих умов та їх важливості на окремих підприємствах, усі компоненти системи повинні становити гармонічну цілісність. Такий постулат приведе до створення відповідної програми рекламних дій - поетапного комплексу збуту інновації, пов'язаного у функціонально-інструментальній сфері з іншими елементами загальної стратегії підприємства.

Пропонуємо виділяти такі етапи комплексу збуту інновацій, як:

I. Вибір маркетингової стратегіï.

II. Формування оптимальної композиції інструментів реалізації вибраної стратегії.

III. Реалізація вибраної стратегії.

IV. Збір і аналіз результатів (досягнення поставленого завдання чи показників). Визначення необхідності коригування.

Перший та другий етапи здійснюється у процесі розроблення товару - стадії, яка передує власне життєвому циклу товару і належить до так званої «нульової» стадії. Останній відводиться дуже важлива роль у життєвому циклі товару, оскільки від якості її виконання залежить успіх нового товару.

Третій і четвертий етапи належать до першої стадії життєвого циклу - виведення товару та його впровадження на ринку. Перша стадія починається з моменту 
надходження товару у продаж та характеризується повільним зростанням обсягу продажу.

На третьому етапі реалізується маркетингова стратегія впровадження нового товару, розподіляється запланований рекламний бюджет на певні інструменти комунікаційного набору. Обсяги збуту починають повільно зростати, і після певного проміжку часу починається четвертий етап - аналіз результатів та порівняння iз встановленими завданнями комплексу.

У процесі обгрунтування стратегій варто виділити найбільш відповідальну і клопітку роботу з аналізу, оцінки і вибору пріоритетів за кожною зі сфер маркетингової діяльності. При цьому варто враховувати взаємозв'язок цілей і стратегій, погодженість у часі, їх підпорядкованість. Очевидно, що прийдеться мати справу з системою критеріїв, тому далі побудуємо модель взаємодії критеріїв у процесі обгрунтування стратегій.

Але насамперед визначимо особливості розроблення стратегій [6]:

- розроблення чи вибір стратегії не повинні завершуватися простим набором тактичних дій, а лише тими встановленими загальними напрямками, які б забезпечили зростання і зміцнення позицій фірми;

- сформульована стратегія повинна використовуватися для розроблення стратегічних проектів методом пошуку. Пошук полягає в тому, щоб установити можливі варіанти розвитку, вибрати найбільш сприйнятливі і відкинути решту як несумісні з вибраною системою критеріїв оцінки і порівняння альтернативних варіантів;

- необхідність дотримання стратегії відпадає, як тільки реальний процес розвитку підприємства досягне наміченого, а показники діяльності досягнуть запланованих;

- у процесі розроблення і вибору стратегії не можна передбачити всіх можливостей, які відкриються під час складання проекту конкретних заходів. Тому доводиться користуватися узагальненою, неповною і недостовірною інформацією про різноманітні альтернативи;

- як тільки в процесі пошуку відкриваються конкретні альтернативи, з'являється і достовірніша інформація, яка ставить під сумнів обгрунтованість початкового вибору. Тому успішне використання стратегії неможливе без зворотного зв'язку. Отже, з метою всебічного оцінювання і вибору однієї з відомих маркетингових стратегій на стадії впровадження нового товару розглянемо їхні характеристики і способи використання.

Відомо, що підприємство, яке зацікавлене виходити на ринок із новим товаром, може застосовувати такі види стратегій, як [6]: інтенсивний маркетинг; вибіркове проникнення; широке проникнення; пасивний маркетинг.

Використання кожної стратегії має певні умови й особливості. Стратегія інтенсивного маркетингу використовується для інновацій, за які споживач готовий сплачувати високу ціну, при цьому потрібно спрямовувати значні кошти на збут (для переконання споживача у перевагах нового товару).

Високий рівень витрат на збут має забезпечити швидке проникнення нового товару на ринок, а висока ціна дає можливість отримати максимально можливий прибуток на одиницю продукції.

Під час вибору стратегії інтенсивного маркетингу підприємство, з огляду на можливу конкуренцію, прагне заздалегідь сформувати у покупців прихильність до нового товару за допомогою засобів реклами та PR, a вже після появи новинки на полицях формувати попит завдяки засобам стимулювання збуту.

Стратегія вибіркового проникнення передбачає продаж нового товару за високою ціною, але за низького рівня витрат на збут. Така стратегія в основному використовується для вузьких спеціалізованих сегментів ринку, де споживачі можуть бути добре поінформовані про появу інновації. 3 огляду на це, попереднє інформування про товар не потрібне, але $\epsilon$ необхідність у присутності та наочності товару на місцях продажу, де би споживачі спеціалізованого вузького сегменту могли $з$ легкістю його знайти.

Тому найважливішим засобом збуту інновацій за стратегією вибіркового проникнення є торговельний i персональний збут, потім доцільно використовувати рекламу у спеціалізованих джерелах, PR та стимулювання збуту (за необхідністю).

Стратегія широкого проникнення сприяє якнайшвидшому проникненню товару на ринок і заволодінню максимальною часткою ринку завдяки низьким цінам і високим витратам на збут інновації.

Дотримання такої стратегії дає змогу інноваційному товару бути присутнім у всіх можливих місцях продажу товару за використання стимулювання торгівлі та потенційних споживачів (приблизно в однаковому відносному розмірі). Реклама та PR відіграють допоміжну роль під час стимулювання до придбання інновації, найчастіше інформуючи про місце та час здійснення покупки.

Стратегія пасивного маркетингу грунтується на припущенні, що низька ціна може більше простимулювати споживачів до покупки, аніж використання комплексу збуту; забезпечує отримання високого прибутку, але при цьому проникнення на ринок і заволодіння певною його часткою може відбуватися дуже повільно.

Розподіл коштів на реалізацію запланованих комунікаційних інструментів збуту інновацій повинен відбуватися залежно від виділеного бюджету і від вибраної маркетингової стратегії.

Для управління вибором певної стратегії збуту інновацій виділимо основні чинники, що впливають на iii вибір, такі як: загальні цілі і завдання підприємства; розмір підприємства; потенціал підприємства; витрати на збут (фінансові обмеження); вид товару; ціна товару (ставлення споживачів до ціни); кон'юнктура ринку (загроза і рівень конкуренціi).

Інформація, яку можна отримати за допомогою певного набору показників, повинна бути повною і достатньою для проведення глибокого аналізу. Тому першим кроком вибору стратегії збуту є пошук необхідної інформації. Умовно поділивши необхідну інформацію за джерелами виникнення (внутрішні показники ді- 
яльності підприємства, характеристика нового товару, особливості цільового ринку), отримуємо такі три групи показників, як:

-внутрішня інформація (поставлені завдання й основні цілі; основні фонди і засоби, фондозабезпеченість власних виробничих потужностей або потужностей посередницьких підприємств; рівень збуту і маркетингу на підприємстві; кількість працівників, рівень забезпеченості кваліфікованими кадрами; фінансові показники діяльності);

- безпосередньо товар (вид товару, його споживчі характеристики; ставлення споживачів до ціни нового товару; можливість задоволення виявленої потреби товаром-субститутом);

- інформація про цільовий ринок (існування потреби в новому товарі; ємність цільового сегменту (ніші); потенційні конкуренти та їхні можливі відповідні реакціï, загроза і рівень конкуренції).

Визначення й аналіз вищенаведеної інформації дає можливість вибрати оптимальну стратегію збуту інновації.

Висновки. Інноваційний розвиток підприємства залежить від інноваційного потенціалу цього під- приємства. Для формування стратегії інноваційного розвитку підприємства доцільно проаналізувати інноваційну діяльність підприємства та визначити ефективність упровадження розробленої стратегії. У сучасних умовах господарювання спостерігається негативний вплив кризових явищ на інноваційний розвиток підприємства. Тому для забезпечення ефективного інноваційного розвитку підприємствам необхідно розробляти заходи щодо підвищення інноваційного потенціалу.

При цьому в умовах обмежених інвестиційних ресурсів процес формування стратегії інноваційного розвитку підприємства повинен передбачати радикальні зміни у моделі економічного розвитку країни. Необхідною передумовою для цього є розроблення відповідної державної стратегії для всіх зацікавлених сторін у суспільстві. Така стратегія передбачає необхідність переходу на європейський шлях розвитку. Для цього необхідно розробити методичний інструментарій для проведення аналітичних досліджень та здійснення прогнозних оцінок в інноваційній системі, а також розробити пропозиції щодо стимулювання інноваційної активності підприємств.

\section{Список літератури:}

1. Александрова В.П. Інноваційний потенціал та його роль в економічному розвитку країни. Наука та наукознавство. 2004. № 2. С. 39-45.

2. Алексєєнко В. Інноваційна політика в системі підприємництва. Стратегія розвитку України. 2006. № 1. C. $332-338$.

3. Амоша А. Інноваційний шлях розвитку України: проблеми та рішення. Економіст. 2005. № 6. С. 28 -32.

4. Гернего Ю.А. Инновационный потенциал экономики Украины. Траектория Науки. 2016. № 2(7).

5. Инновационный менеджмент: учебное пособие; под ред. д.э.н., проф. Л. Н. Оголевой. Москва: ИНФРА-М, 2003. 238c.

6. Інноваційний поступ економіки України : проблеми, тенденції, потенціал зростання : монографія; за ред. 3. Юринець, Л. Гнилянської. Львів: Ліга-Прес, 2013. 296 с.

\section{References:}

1. Aleksandrova V.P. (2004) Innovatsiinyi potentsial ta yoho rol v ekonomichnomu rozvytku krainy [Innovative potential and its role in the economic development of the country]. Nauka ta naukoznavstvo, vol. 2, pp. 39-45.

2. Aleksieienko V. (2006) Innovatsiina polityka v systemi pidpryiemnytstva [Innovation policy in the business system]. Stratehiia rozvytku Ukrainy, vol. 1, pp. 332-338.

3. Amosha A. (2005) Innovatsiinyi shliakh rozvytku Ukrainy: problemy ta rishennia [Innovative way of development of Ukraine: problems and solutions]. Ekonomist, vol. 6, pp. 28-32.

4. Herneho Yu.A. (2016) Ynnovatsyonnыi potentsyal эkonomyky Ukraynы [Innovative potential of Ukraine’s economy]. Traektoryia Nauky. vol. 2, no. 7.

5. Oholevoi L.N. (2003) Ynnovatsyonnыi menedzhment: uchebnoe posobye [Innovation management]. Moscow: YNFRA-M (in Russian).

6. Yurynets Z, Hnylianskoi L (2013). Innovatsiinyi postup ekonomiky Ukrainy: problemy, tendentsii, potentsial zrostannia: monohrafiia [Innovative progress of Ukraine's economy: problems, trends, growth potential: monograph]. Lviv: Liha-Pres (in Ukrainian). 